\title{
Entity's operations under the changes in the Conceptual Framework for Financial Reporting
}

\author{
Galina Machinistova ${ }^{1, *}$ \\ ${ }^{1}$ Plekhanov Russian University of Economics, 36, Stremyanny lane, Moscow, Russia
}

\begin{abstract}
The subject of the study is the Conceptual Framework that lays the foundation for the preparation of information presented in International Financial Reporting Standards. The significance of the research topic is explained by the increasingly active use of international financial reporting standards in accounting of various countries. The purpose of the study is to assess the impact of changes made to the Conceptual Framework for Financial Reporting in 2018 on the accuracy of the information contained in the financial statement. The article focuses on the need to study the conceptual framework for financial reporting for a relevant and understandable reflection of the objects of financial reporting. The methodological basis of the work includes general scientific methods, such as analysis and synthesis, detailing and generalization, comparison and abstraction, models and a method of system and chronological analysis, etc.
\end{abstract}

\section{Introduction}

In order to do business successfully, as well as to make optimal decisions, entity's management must be able to read, understand and analyze financial statements. Therefore, it is necessary for reporting to be equally comprehensible to all the users. Thus, this requires that the reporting is subject to certain general rules of the preparation of accounting information. At the present time, when business relations between entities of various states are rapidly developing, this task faces not only national accounting control systems, but also the entire international accounting community.

One of the most important documents that determine the main areas of the preparation of information in the accounting conducted in accordance with the requirements of IFRS, is the Conceptual Framework for Financial Reporting (hereinafter - the Framework). This defines the principles for reflecting accounting information, as well as requirements for recognizing objects in accounting, and for evaluating these objects.

The Conceptual Framework was first issued in 1989. It was called "Framework for the Preparation and Presentation of Financial Statements". In 2010, it was revised with significant changes in the wording of accounting principles and financial reporting objects.

The Conceptual Framework influences the comprehension of the information reflected in certain International Financial Reporting Standards. However, the Conceptual Framework is not considered to be a standard. It outlines the framework within which

*Corresponding author: Sg6457@mail.ru 
standards should be formed. In case requirements for preparation of information differ from the Conceptual Framework, the information reflected in accordance with the standard would prevail. In case none of standards could be applied to an existing situation, the Conceptual Framework should be referred to.

On March 29, 2018, the International Accounting Standards Board (IASB) released a revised version of the Conceptual Framework for Financial Reporting (IFRS Framework), which contains quite many changes compared to the previous version.

The article provides the consideration of changes in Conceptual Framework for Financial reporting of 2018, including the changes that affected the clarification of terminology or forms of information presentation.

\section{Materials}

Most notably, the document structure has been changed. Instead of three chapters, the new Conceptual Framework consists of 8 chapters, one of which contains completely new information on reporting entities.

The purpose of the Conceptual framework which is to provide financial information on a reporting entity that is useful for accounting users such as investors, various creditors, including lenders in the process of making decisions on granting loans and borrowings or investing in the entity, has remained unchanged.

Figure 1 demonstrates the classification of qualitative characteristics of the financial reporting according to the Framework of 2018.

It should be noted that the first version of the Conceptual Framework included such principles as neutrality and prudence (caution). In the Framework of 2010, the neutrality principle is considered to be a component of faithful presentation of information, however, the prudence principle is not included. In the Framework of 2018, the fundamental characteristic of financial reporting, such as faithful presentation, contains the requirement of neutrality and prudence.
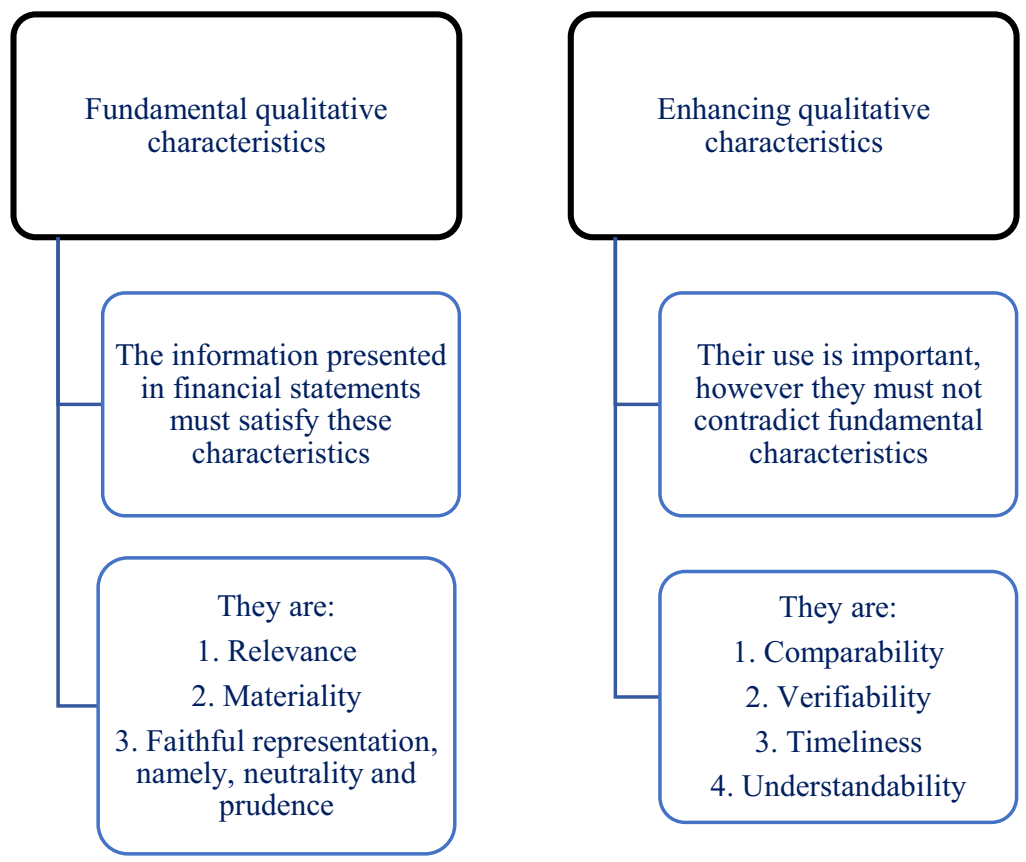

Fig. 1. Qualitative characteristics of accounting reporting. 
The main purpose of preparing and presenting financial reporting has also been identified.

The financial statements should provide financial information on the assets of an entity in question, its liabilities, equity, income, expenses and money flows. Such information is useful for users of accounting statements in the process of assessing the prospects of future net cash flows to the reporting entity, as well as in evaluating the performance of the entity's management concerning the control of economic resources (7).

Otherwise speaking, the Framework approves the necessary scope of financial statements, namely:

- Balance sheet (Statement of financial position)

- Profit and Loss Statement (Statement of financial results)

- Other statements and notes that provide information about recognised assets, liabilities, equity, income and expenses, as well as the nature of these elements of financial statements and associated risks. (7)

Other statements and notes disclose information about

- assets and liabilities that have not been recognised, including information about their nature and the risks arising from them;

- cash flows;

- contributions from holders of equity claims and distributions to them;

- the methods, assumptions and judgements used in estimating the amounts presented or disclosed, and changes in those methods, assumptions and judgements. (7).

In other words, the Framework emphasizes the main purpose of financial statements as information for assessing the financial position of an entity (based on the balance sheet) and its financial performance (based on the profit and loss statement) and its cash flows.

It should be noted that the financial performance of an entity could be reflected by accrual accounting or past cash flows. Conceptual framework requires that financial performance is reflected by accrual accounting, since this approach allows to determine the actual performance during a period. However, at the same time, the users need information about the entity's ability to generate cash flows in order to provide the necessary resources. Therefore, information about cash flows, which actually reflects the financial performance by past cash flows, is considered to be extremely important. And, a great attention is paid to it in Conceptual framework. The correlation between these two approaches allows to indirectly draw a cash flow statement.

One of the main areas of the Framework is the reflection of the qualitative characteristics of useful financial information. In essence, this refers to accounting policies, that is the basic rules that must be followed by information of financial statements in order to be understandable, and therefore useful to users.

As in the previous version, the fundamental qualitative characteristics of financial statements are relevance and faithful representation.

The important information about reporting entities is presented in the Framework of 2018. It covers the basic rules for the presentation of financial statements, its content and a reporting period. It is important that the analytical role of each of financial statement is emphasized.

The concept of the reporting entity and the types of financial statements are completely new.

A reporting entity is an entity that is required, or chooses, to prepare financial statements. (7)

It clarifies which financial statements are called "consolidated" and which are called "unconsolidated",

The Framework defines a completely new concept of "combined financial statements". Such statements are prepared when a reporting entity comprises several entities that are not linked by a parent-subsidiary relationship. 
In order for the information to be identically perceived by different users, in addition to the general rules for the preparation of information, that is accounting policies, it is also necessary to implement two important aspects. It is important to equally recognize objects in financial statements and equally evaluate them.

The requirements for the recognition of objects in financial statements are one of the most important aspects of unification of accounting information, which makes the information equally understandable to different users of financial statements.

Recognition is the process of capturing for inclusion in the statement of financial position or the statement of financial performance an item that meets the definition of one of the elements of financial statements - an asset, a liability, equity, income or expenses. (8)

Another main aspect of unification of financial information is the assessment of accounting objects. It is important to focus on the fact that the assessment, along with the accounting policies and the requirements for the recognition of objects in the financial statements, is, as already noted, the main requirement that allows the equal measurement of the financial position of an entity and its financial performance by various users of the financial statements.

The measurement bases are:

- historical cost;

- current value;

- fair value;

- value in use and fulfilment value;

- current cost.

Moreover, the factors that must be taken into account when selecting measurement basis are identified.

The requirements for presentation and disclosure of information in financial statements are also considered. Furthermore, the role of financial statements as a means of effective communication between market entities is emphasized. In addition, the classification of elements of financial statements is described, and the preparation of information about other comprehensive income is considered, which is not present in the previous version of the Framework.

A fairly large part of the Framework of 2018 is devoted to the elements of financial statements. It should be noted that the elements of financial statements reflected are exactly the same as in the Framework of 2010 (in fact, the same elements were reflected in the original version of the Conceptual framework of 1989).

The changes of the basic definitions in the new Conceptual Framework are considered in the research at hand.

The overall picture of the changes is displayed in Table 1.

Table 1. Comparison of definitions of elements of financial statements in the Conceptual Frameworks of 2010 and 2018.

\begin{tabular}{|c|l|l|}
\hline $\begin{array}{l}\text { Element of the } \\
\text { financial } \\
\text { statements }\end{array}$ & $\begin{array}{l}\text { The Conceptual Framework of } \\
\mathbf{2 0 1 0}\end{array}$ & $\begin{array}{l}\text { The Conceptual Framework of } \\
\mathbf{2 0 1 8}\end{array}$ \\
\hline Assets & $\begin{array}{l}\text { An asset is a resource controlled } \\
\text { by the entity as a result of past } \\
\text { events, from which future economic } \\
\text { benefits are expected to flow to the } \\
\text { entity }\end{array}$ & $\begin{array}{l}\text { A present economic resource } \\
\text { controlled by the entity as a result of } \\
\text { past events. } \\
\text { An economic resource is a right } \\
\text { that has the potential to produce } \\
\text { economic benefits }\end{array}$ \\
\hline Liabilities & $\begin{array}{c}\text { A liability is a present obligation } \\
\text { of the entity arising from past events, }\end{array}$ & $\begin{array}{c}\text { A present obligation of the entity } \\
\text { to transfer an economic resource as a }\end{array}$ \\
\hline
\end{tabular}




\begin{tabular}{|c|c|c|}
\hline & $\begin{array}{l}\text { the settlement of which is expected to } \\
\text { result in an outflow from the entity of } \\
\text { resources embodying economic } \\
\text { benefits. }\end{array}$ & result of past events \\
\hline Equity & $\begin{array}{l}\text { Equity is the residual interest in } \\
\text { the assets of the entity after } \\
\text { deducting all its liabilities. }\end{array}$ & $\begin{array}{l}\text { Equity is the residual interest in } \\
\text { the assets of the entity after deducting } \\
\text { all its liabilities. }\end{array}$ \\
\hline Income & $\begin{array}{l}\text { Income is increases in economic } \\
\text { benefits during the accounting period } \\
\text { in the form of inflows or } \\
\text { enhancements of assets or decreases } \\
\text { of liabilities that result in increases in } \\
\text { equity, other than those relating to } \\
\text { contributions from equity } \\
\text { participants. }\end{array}$ & $\begin{array}{l}\text { Income is an increases in assets, } \\
\text { or decreases in liabilities, that result } \\
\text { in increases in equity, other than those } \\
\text { relating to contributions from holders } \\
\text { of equity claims }\end{array}$ \\
\hline Expenses & $\begin{array}{l}\text { Expenses are decreases in } \\
\text { economic benefits during the } \\
\text { accounting period in the form of } \\
\text { outflows or depletions of assets or } \\
\text { incurrences of liabilities that result in } \\
\text { decreases in equity, other than those } \\
\text { relating to distributions to equity } \\
\text { participants. }\end{array}$ & $\begin{array}{l}\text { Expenses are decreases in assets, } \\
\text { or increases in liabilities, that result in } \\
\text { decreases in equity, other than those } \\
\text { relating to distributions to holders of } \\
\text { equity claims }\end{array}$ \\
\hline
\end{tabular}

As in the previous version, the Conceptual Framework of 2018 provides definitions of the concepts of capital maintenance, namely, financial and physical. Both concepts refer to an increase of capital as a result of productive capacity of an entity. Under financial capital maintenance the profit is earned in the form of an increase in the net assets of the entity. And under physical capital maintenance the profit is earned in the form of an excess of the physical productive capacity of the reporting entity at the end of a reporting period over the same indicator at the beginning of the same reporting period.

\section{Results}

The document structure has become clearer. The connection between the concepts, definitions and the essence of the information presented has appeared.

In the definition of an economic resource, that is, an asset, the emphasis on the right, that has the potential to produce economic benefits and expands the concept of an asset, is of great importance. Otherwise speaking, at the present time, in order to recognize an asset, it is necessary that there are three components:

- the right to use the resource,

- potential to produce economic benefits and

- control.

The last component is especially important in connection with the issuance of the new leases standard, IFRS 16 Leases, in which there is a right of use asset (ROU asset). It should be noted that any right of an entity is an asset.

The Conceptual Framework for Financial Reporting of 2018 provides a comprehensive description of both assets and liabilities for various situations in more detail than they are described in the Conceptual Framework for Financial Reporting of 2010. The Framework of 2018 allows to use these definitions of elements of financial statements in various possible situations that might arise in entity's operations.

The new Framework emphasizes that a liability is an obligation to transfer a resource to another entity. In addition, the obligation might arise from business practice, accounting 
policies or any other statements of the entity, that is, the concept of a liability is expanded.

\section{Discussion}

According to the author, the reintroduction of the concept of prudence to the Conceptual Framework is extremely important, since it allows to enter certain estimated and not entirely accurate data in the financial statements, that, nevertheless, improve the quality of the information provided. This refers to events occurring after the reporting date, to contingencies, especially to the recognition of contingent liabilities, and to other situations in which the entity operates under conditions of uncertainty.

IFRS does not contain any requirements for the preparation of combined financial statements, however, the term has been included in the new Framework. Therefore, the definition of this concept is not clear. Most likely, in the near future, a standard that would describe the requirements for the preparation of combined financial statements is expected to be introduced.

The definition of unconsolidated financial statements includes the concepts of "separate financial statements" and "individual financial statements". They are not directly referred to in the Framework, but the preparation of information in unconsolidated financial statements is self-explanatory. To learn more about the concept of separate financial statements, IAS 27 Separate Financial Statements should be referred to.

\section{Conclusions}

The Framework emphasizes the main purpose of financial statements as information for assessing the financial position of a company (based on the balance sheet) and its financial performance (based on the profit and loss statement) and its cash flows.

The concept approves the necessary scope of financial statements that allows to assess the financial position of an entity, that is the Statement of financial position, as well as financial performance of an entity, that is the Profit and Loss Statement, and cash flows in various activity areas of an entity, that is the Cash Flow Statement.

The Framework of 2018 defines the concept of economic benefits more clearly. In the previous version, the definition was rather vague, but now it is clear that economic benefits are not an asset, since they cannot be controlled. And the concept of an asset is associated with the possibility of controlling it.

Unnecessary information has been removed from the definition of expenses, since it is quite difficult to determine what depletion of assets is. This term is excessive in defining the entity's expenses. The reference to a decrease in economic benefits of the entity has also been removed, since the outflows of assets denotes the loss of economic benefits associated with these assets.

In addition, as noted above, the concept of an asset (an economic resource) is associated with the potential to produce economic benefits, which reflects the essence of an asset.

Furthermore, the characteristic of increase in assets, which is expressed through improving the quality of assets, has been excluded from the definition of income. This is due to the fact that any quality improvement associated with an increase in value would give a clear increase in an asset, and if it is not associated with an increase in value, the entity would not make a profit. There would only be the possibility of earning a large income in the future.

It should be especially noted that the distinction of the new Conceptual Framework is the reflection of capital maintenance adjustments. It is considered to be important, since the entity's equity changes not only as a result of operating capability of the entity, but also as a 
result of the impact of various external factors on the entity's operations. Such adjustments are not regarded as the entity's income and expenses and are included in the statement of other comprehensive income. It is worthwhile noting that in paragraph 7, IAS 1 provides a list of situations that are recognized as other comprehensive income. Moreover, this list does not include a share premium, since it is considered as part of the authorized capital. According to the author, although the share premium is directly related to the formation of the authorized capital, it is a capital increase that the entity could not influence. It is proposed to consider the equity of an entity as a value consisting of three parts:

- authorized capital is a value that reflects the amount of the initial owner's contribution (this value is adjusted by the amount of shares repurchased from shareholders) and demonstrates the minimum guarantee for creditors;

- capital surplus is a value that reflects the amount of capital increase that occurs not due to the entity's operations, but due to certain external events (and the share premium appears as a result of the market situation);

- retained earnings are the amount that reflects the increments of entity's assets that occur due to the effective performance of the entity.

It is evident that there is no concept of capital surplus in IFRS. The balance sheet simply reflects the other components of a capital. However, in the opinion of the author, it is possible to define all other components of capital in one term, as it is defined in Russian accounting. Thus, it would become clear that the wealth of owners - capital - could be influenced not only by the performance of the entity's managers. It becomes apparent that all other changes in capital are related to various external conditions. Therefore, in Russian accounting, in the process of development of the new law "On accounting", the concept of "financial life results" was introduced instead of the concept of "financial performanceresults" of an entity. For instance, the upward revaluation of fixed assets gives rise to an increase in equity, and consequently, to an increase in the wealth of owners. However, the entity does not make any efforts. That is, the increase in equity occurs due to certain events unrelated to the entity's managers.

According to the author, in order to understand the concept of "equity", it is extremely important to consider the sections of equity this way.

The other sections of equity are part of one of the components of equity. For instance, the value of shares repurchased from shareholders has already been mentioned. It is directly related to the formation of the authorized capital, therefore, it allows to assess the value at a certain moment.

In case, the capital surplus is considered, it is necessary to allocate a revaluation reserve from it, since all other components of really do not change as a result of activities, and the revaluation reserve might appear and decrease to zero. However, it should be noted that, according to IAS 1 Presentation of Financial Statements, capital surplus includes the results of many events, which might also change the amount of capital surplus every year. It has already been mentioned that there is no separate concept of capital surplus in IFRS. However, in fact, this refers to all the amounts that the entity reflects in other comprehensive income.

In terms of retained earnings, the amount of reserve capital (reserve fund) is allocated from it, which, denotes the minimum degree of stability of the entity. Other funds might be allocated in internal reporting in order to control the entity's use of its retained earnings.

Thus, the new Conceptual Framework of IFRS allows to produce an adequate information base for users of financial statements so that entities management could make informed decisions. 


\section{References}

1. N.V. Balikhina, G.E. Mashinistova, Iu.K. Kharakoz, Ekonomika i predprinimatel'stvo 8-3(85) (2017)

2. N.V. Balikhina, G.E. Mashinistova, Iu.K. Kharakoz, Ekonomika i predprinimatel'stvo 6 (2017)

3. I.M. Dmitrieva, Iu.K. Kharakoz, Zhurnal Auditor 1-2 (2015)

4. E. Zakhodiakina, Elektronnyi zhurnal MSFO na praktike 9 (2018)

5. E. Zakhodiakina, Elektronnyi zhurnal MSFO na praktike 10 (2018)

6. E. Vasilyeva, A. Mottaeva, E3S Web of Conferences 91, 08051 (2019) doi.org/10.1051/e3sconf /20199108051

7. L.N. Nikolova, D.G. Rodionov, M.A. Bahauovna, International Journal of Economics and Financial 6(2), 246-252 (2016)

8. IAS 1 Presentation of financial statements, http://msfo-dipifr.ru/msfo/

9. Official website of the Ministry of Finance of the Russian Federation, http://www1.minfin.ru/ru/accounting/accounting/legislation/positions/

10. Official website of the International Accounting Standards Board (IASB), http://www.iasb.org/

11. Official website of the International Financial Reporting Standards (IFRS Foundation), http://www.ifrs.org/

12. I.M. Dmitrieva, G.E. Mashinistova, Kharakoz Finansovyi i upravlencheskii uchet $v$ usloviiakh perekhoda na MSFO. Teoriia i praktika: Monografiia (M., IuNITI-DANA, 2014) 